\title{
PENGEMBANGAN BAHAN AJAR MATEMATIKA BERAZASKAN EXPERIENTIAL LEARNING UNTUK MENINGKATKAN KEMAHIRAN BERPIKIR TINGKAT TINGGI SISWA SMP
}

\author{
Elfis Suanto ${ }^{1}$ Armis $^{2}$, Suhermi ${ }^{3}$ \\ 1,2,3 Universitas Riau \\ Elfis.suanto@lecturer.unri.ac.id
}

\begin{abstract}
This research aims to develop mathematics teaching materials of statistics and opportunities based on experiential learning approach that can be used as a learning resource by students of grade VIII Junior High School. This research and development using ADDIE model. The ADDIE model consists of five stages namely Analysis, Design, Development, Implementation and Evaluation. Data collection instruments are used in the form of closed and open validation sheets to score validity data and advice sheets used to request improvement advice on teaching materials from teachers as educational practitioners. Based on the analysis of data obtained data about material quality teaching materials; and the suitability of teaching materials based on experiental learning approach is very valid; conformity of teaching materials with didactic conditions; the suitability of teaching materials with good language and constructs; the suitability of teaching materials with technical conditions is valid. It can be concluded that mathematics teaching materials of satatistics and opportunities based on experiential learning that have been developed deserve to be used as a learning resource for junior high school students.
\end{abstract}

Keywords: experiential learning, higher order of thinking skill, learning resources

\begin{abstract}
Abstrak
Penelitian ini bertujuan untuk mengembangkan bahan ajar matematika materi Satatistika dan Peluang berazaskan pendekatan experiential learning yang dapat digunakan sebagai sumber belajar oleh siswa kelas VIII SMP/MTs. Penelitian ini berupa penelitian dan pengembangan menggunakan model ADDIE. Model ADDIE terdiri atas lima tahapan yaitu Analysis, Design, Development, Implementation dan Evaluation. Instrumen pengumpul data yang digunakan berupa lembar validasi tertutup dan terbuka untuk menjaring data kevalidan bahan ajar dan lembar saran yang digunakan untuk meminta saran perbaikan bahan ajar dari guru sebagai praktisi pendidikan. Berdasarkan hasil analisis data diperoleh data kualitas materi bahan ajar; dan kesesuaian bahan ajar berdasarkan pendekatan experiental learning adalah sangat valid; kesesuaian bahan ajar dengan syarat didaktik; kesesuaian bahan ajar dengan ketatabahasaan yan baik dan konstruk; kesesuaian bahan ajar dengan syarat teknis adalah valid. Dapat disimpulkan bahwa bahan ajar matematika materi Satatistika dan Peluang berazaskan experiential learning yang telah dikembangkan layak digunakan sebagai sumber belajar bagi siswa SMP/MTs.
\end{abstract}

Kata kunci: bahan ajar, experiential learning, kemahiran berpikir tingkat tinggi

\section{PENDAHULUAN}

Kemahiran berpikir tingkat tinggi merupakan kemampuan siswa dalam menganalisis serta melibatkan proses berpikir kompleks dan dituntut untuk berpikir kritis dan kreatif dalam memecahkan masalah. (Abosalem, 2016; King, Goodson, \& Rohani, 2011; Ngah, Ismail, Tasir, \& Said, 2017, Kusuma, dkk, 2017; Nursalam, dkk, 2018). Kemahiran berpikir tingkat tinggi (KBTT) di Indonesia telah dinyatakan sebagai salah satu tujuan pembelajaran dalam kurikulum 2013 (K13) revisi 2017 yang mesti dicapai oleh siswa. Pradigma pendidikan dari pengajaran yang berpusat pada guru ke arah pembelajaran yang berpusat kepada siswa. Paradigma ini menuntut guru agar lebih kreatif dalam membuat bahan ajar yang inovatif, sehingga memungkinkan siswa untuk mengembangkan potensi 
dan kemahiran berpikir secara lebih optimal. Penyempurnaan kurikulum terakhir dilakukan adalah K13 revisi 2017 yang mengintegrasikan kemahiran berpikir tingkat tinggi (high order thinking skills (HOTS)) dan keterampilan abad 21 dengan menggunakan pendekatan TPACK (Technological and Pedagogical Content Knowledge).

Berdasarkan studi pendahuluan di beberapa daerah di provinsi Riau, ditemukan kenyataan bahwa KBTT siswa SMP/MTs masih rendah. Hal ini sesuai dengan hasil penelitian bahwa siswa belum mampu menguasai permasalahan matematika yang memuat KBTT (Kartini 2011, Mahdiansyah \& Rahmawati 2014). Siswa sukar menyelesaikan soal-soal pembuktian, evaluasi, generalisasi, dan sukar menghubungkaitkan antara satu konsep dengan konsep lainnya (Kartini 2011, Elfis Suanto 2017).

Keterbatasan kemampuan guru matematika SMP dalam membuat bahan ajar inovatif berdesain dan berkonteks lingkungan siswa yang sesuai dengan tuntutan K13 revisi 2017 telah menjadi masalah tersendiri. Di satu sisi, diyakini bahwa pemanfaatan desain dan konteks lingkungan pelajar sebagai sumber belajar dapat memberi motivasi belajar yang lebih baik, lebih mudah diterima dan pengalaman belajar yang diperoleh lebih bertahan lama (Phonapichat et al, 2014, Alim, 2020). Memahami masalah ini, perlu upaya membantu guru dalam mengembangkan bahan ajar berdesain lingkungan siswa agar implementasi K13 lebih berkualitas yang bermuara pada optimalisasi kemampuan berpikir tingkat tinggi dan motivasi belajar matematika siswa serta terkembang kannya keterampilan abad 21.

Terkait penanaman konsep matematika yang bersifat abstrak dan imanjinatif, guru dan siswa perlu dibantu. Untuk membantu dan memberi kemudahan kepada guru dan siswa, maka melalui penelitian ini peneliti mengembangkan bahan ajar matematika untuk SMP kelas VIII menggunakan experiential learning dari David Kolb (1984). Pendekatan tersebut diyakini merupakan pendekatan pembelajaran yang dapat meningkatkan kemahiran berpikir tingkat tinggi siswa terutama pada pembelajaran matematika (Evans, Forney \& Guido-Di Brito 1998; Silberman, 2015; Raga, 2014; Sari 2013). Dalam experiential learning siswa dilibatkan secara aktif dalam proses pembelajaran melalui tahapan pemberian pengalaman konkrit, penglibatan siswa dalam pengamatan yang bersifat reflektif, keterlibatan siswa membuat konseptualisasi dan penerapan konsep sebagai proses membangun KBTT siswa. Berikut disajikan penjabaran dari langkah-langkah experiential learning.

1. Concrete experience (felling): Belajar dari pengalaman-pengalaman yang spesifik. Peka terhadap situasi.

2. Reflective observation (watching): Mengamati sebelum membuat suatu keputusan dengan mengamati lingkungan dari perspektif -perspektif yang berbeda.

3. Abstract conceptualitation (thinking): Analisis logis dari gagasan-gagasan dan bertindak sesuai pemahaman pada suatu situasi.

4. Active experimentation (doing): Kemampuan untuk melaksanakan berbagai hal dengan orangorang dan melakukan tindakan berdasarkan peristiwa, termasuk pengambilan resiko. 
Implikasi dari konsep tersebut dijadikan pegangan dalam menghadapi pengalaman baru. Permasalahannya adalah bagaimana mendesain dan mengembangkan bahan ajar berdesain kawasan daerah di Riau berbasis experiential learning yang valid dan praktis sehingga layak digunakan dalam proses pembelajaran.

Berdasarkan pemikiran dan rasionalitas di atas, perlu penelitian secara mendalam dan komprehensip tentang pengembangan bahan ajar matematika yang dimaksud terkait validitas dan dampaknya terhadap KBTT siswa. Oleh sebab itu dalam penelitian ini dikembangkan bahan ajar berazaskan experiential learning materi Statistika dan Peluang untuk kelas VIII SMP. Statistika dan Peluang adalah topik-topik pelajaran yang dianggap sulit oleh siswa dan guru.

Berdasarkan uraian di atas, rumusan masalah dalam penelitian ini adalah "Bagaimana mengembangkan bahan ajar matematika materi Statistika dan Peluang berazaskan experiential learning yang valid dan praktis?". Penelitian ini bertujuan untuk mengembangkan bahan ajar matematika materi Statistika dan Peluang berazaskan experiential learning yang valid dan praktis. Maksud dari penelitian ini adalah sebagai berikut:

1. Menghasilkan bahan ajar matematika berazaskan experiential learning valid dan praktis.

2. Mendeskripsikan kevalidan dari bahan ajar matematika yang telah dikembangkan berdasarkan validasi oleh para ahli.

3. Mendeskripsikan kepraktisan dari bahan ajar matematika yang telah dikembangkan berdasarkan respon guru dan siswa setelah dilakukan ujicoba kelompok kecil.

Bahan ajar yang dikembangkan bermanfaat bagi guru sebagai sarana mengaktifkan siswa dalam pembelajaran matematika, dan dapat dijadikan sebagai sumber belajar oleh siswa untuk mempermudah konstruksi ilmu secara mandiri.

\section{METODE}

Penelitian ini termasuk penelitian dan pengembangan (Research and Development) yang mengkaji berbagai literatur dari buku sumber dan jurnal. Penelitian dan pengembangan merupakan penelitian yang bertujuan untuk menghasilkan produk baru atau memperbaiki suatu produk melalui proses pengembangan. Produk dari penelitian ini adalah bahan ajar matematika materi Statistika dan Peluang berazaskan experiential learning untuk siswa kelas VIII SMP.

Model yang digunakan untuk mengembangkan model pembelajaran berazaskan experiential learning ini adalah model ADDIE. ADDIE merupakan akronim dari tahapan proses pengembangan yang meliputi: analyze, design, develop. implement, evaluate (Brown and Green. 2011). Tahap evaluasi juga dilakukan pada setiap tahapan lainnya, namun hanya sebatas revisi produk. 


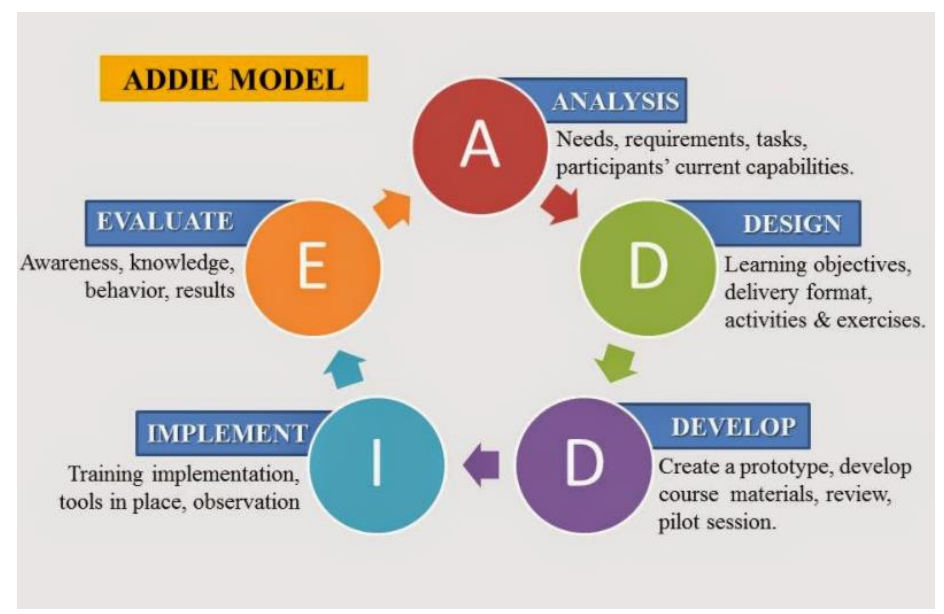

Gambar 1. Tahapan Model ADDIE

\section{Prosedur Pengembangan}

Dalam penelitian ini, peneliti menyusun prosedur kegiatan pengembangan sebagai berikut.

\section{Analisis (analysis)}

a. Menganalisis kompetensi dasar yang harus dicapai pada materi Statistika dan Peluang

b. Menganalisis sub-sub materi Statistika dan Peluang

c. Menganalisis indikator KBTT siswa yang dikaji.

d. Menganalisis langkah-langkah model experiental learning.

\section{Perancangan (design)}

a. Merancang pengembangan bahan matematika ajar berazaskan experiental learning

b. Merancang instrumen kevalidan bahan ajar (angket kevalidan)

c. Merancang instrumen kepraktisan bahan ajar (angket guru dan respon siswa)

\section{Pengembangan (development)}

a. Mengembangkan bahan ajar matematika berazaskan experiental learning berdasarkan kajian literatur.

b. Melakukan validasi bahan ajar kepada dua orang validator.

c. Melakukan revisi bahan ajar sesuai saran validator.

d. Melakukan ujicoba bahan ajar pada enam orang siswa

e. Mengedarkan angket respon kepada siswa untuk melihat kepraktisan bahan ajar.

f. Merevisi bahan ajar berdasarkan hasil ujicoba sehingga menghasilkan bahan ajar yang praktis dan layak pakai.

\section{Data dan instrumen}

Sejalan dengan masalah maka jenis data pada penelitian ini yaitu:

\section{Data Kuantitatif}

Data kuantitatif merupakan data yang berwujud angka-angka sebagai hasil observasi atau pengukuran. Data kuantitatif dalam penelitian ini adalah penilaian validator terhadap bahan ajar. 


\section{Data Kualitatif}

Data kualitatif merupakan data yang menunjukan kualitas atau mutu sesuatu yang ada, baik keadaan, proses, peristiwa/kejadian dan lainnya yang dinyatakan dalam bentuk pernyataan atau berupa kata-kata. Data kualitatif pada penelitian ini adalah tanggapan dan saran validator, guru, dan siswa terhadap bahan ajar yang dikembangkan.

Instrumen validasi dan kepraktisan bahan ajar dalam penelitian ini dikembangkan berdasarkan adaptasi dari Sa'dun Akbar (2016) meliputi aspek (1) relevansi, (2) keakuratan, (3) kelengkapan sajian, (4) sistimatika sajian, (5) kesesuaian sajian dengan tuntutan pembelajaran yang terpusat pada siswa, (6) cara penyajian, (7) kesesuaian bahasa dengan kaidah bahasa Indonesia yang baik dan benar, dan (8) keterbacaan dan kekomunikatifan. Aspek dari instrument yang digunakan dalam penelitian ini adalah (1) Kualitas Materi Bahan Ajar, (2) Kesesuaian Bahan Ajar berdasarkan Pendekatan Experiental Learning, (3) Kesesuaian Bahan Ajar dengan Syarat Didaktik, (4) Kesesuaian Bahan Ajar Dengan Ketatabahasaan Yang Baik Dan Konstruk, dan (5) Kesesuaian Bahan Ajar dengan Syarat Teknis.

Bentuk dari lembar penilaian yang digunakan berupa angket tertutup (skala Likert 4,3,2,1) dan angket terbuka. Angket tertutup digunakan untuk mendapatkan skor penilaian dan angket terbuka digunakan untuk mendapatkan komentar dan saran perbaikan dari validator.

\section{Analisis Data}

Hasil validasi bahan ajar berupa data kuantitatif dianalisis menggunakan rumus:

$$
\bar{M}_{v}=\frac{\sum_{i=1}^{n} \bar{V}_{i}}{n}
$$

$\bar{M}_{v}:$ rata-rata total validitas

$\bar{V}_{i}$ : rata-rata validasi validator ke- $i$

$n$ : banyaknya validator

Kriteria validitas analisis rata-rata hasil validasi disajikan dalam tabel 1 berikut.

\section{Tabel 1.}

Kategori Validitas Bahan Ajar

\begin{tabular}{|c|c|}
\hline Interval & Kategori \\
\hline $3,25 \leq \bar{x}<4$ & Sangat Valid \\
\hline $2,50 \leq \bar{x}<3,25$ & Valid \\
\hline $1,75 \leq \bar{x}<2,50$ & Kurang Valid \\
\hline $1,00 \leq \bar{x}<1,75$ & Tidak Valid \\
\hline
\end{tabular}

Sumber: Sugiyono, 2019

\section{HASIL}

Berdasarkan tahap-tahap pengembangan yang telah dilaksanakan, dihasilkan suatu produk berupa bahan ajar matematika materi Satatistika dan Peluang berazaskan experiential learning untuk meningkatkan KBTT siswa SMP yang sesuai dengan keadaan lokal sekolah-sekolah yang berada di provinsi Riau. 
Pada tahap analysis, aktiviti utama dilakukan analisis keperluan pembangunan bahan baru dan menganalisis kebolehan dan syarat-syarat pembangunan bahan tersebut. Hasil dari tahap analisis diperoleh beberapa aspek pembangunan bahan baru meliputi kualitas materi bahan ajar, kesesuaian dengan pendekatan Experiental Learning, kesesuaian dengan syarat didaktik, kesesuaian dengan ketatabahasaan yang baik dan konstruk, kesesuaian dengan syarat teknis, serta memperhatikan penampilan bahan ajar.

Dalam perancangan bahan ajar, peringkat desain memiliki kesamaan dengan merancang kegiatan belajar mengajar. Kegiatan ini merupakan proses sistematik yang dimulai dari menetapkan tujuan pambelajaran, merancang skenario kegiatan pembelajaran sesuai dengan langkah Experiental Learning, merancang materi pembelajaran dan alat penilaian pencapaian KBTT. Rancangan bahan ajar ini bersifat konseptual dan mendasari proses pembangunan berikutnya. Rancangan ini disajikan dalam bentuk silabus yang kemudian disajikan dalam bahan ajar yang dikembangkan.

Pengembangan (development) dalam model ADDIE berupa kegiatan realisasi rancangan produk. Dalam peringkat desain, disusun kerangka konseptual penerapan bahan ajar baru. Dalam peringkat pengembangan, kerangka yang masih konseptual tersebut direalisasikan menjadi produk yang siap diimplementasikan. Kegiatan awal yang disusun adalah panduan penggunaan bahan ajar. Pada awal pembelajaran disajikan pengantar materi pada setiap bagian awal materi statistika dan peluang. Selanjutnya disusun bahan ajar yang berisikan kegiatan kegiatan siswa ke dalam beberapa subbab materi sesuai dengan silabus yang telah dikembangkan.

Setelah bahan ajar selesai dirancang, bahan ajar disahkan (divalidasi) oleh 2 orang pakar yang terdiri dari satu pakar materi dan satu pakar pembelajaran.

Berdasarkan kategori validitas bahan ajar, nilai validasi yang diperoleh menunjukkan bahwa bahan ajar yang dikembangkan dapat dikategorikan valid. Berikut pembahasan mengenai nilai validasi bahan ajar. Tabel 2 di bawah ini menyajikan hasil falidasi untuk setiap indicator.

Tabel 2.

Hasil validasi bahan Ajar Perindikator

\begin{tabular}{|c|l|c|c|c|}
\hline \multirow{2}{*}{ No } & \multicolumn{1}{|c|}{ Aspek Penilaian } & \multicolumn{3}{c|}{ Skor Penilaian } \\
\cline { 3 - 5 } & \multicolumn{1}{|c|}{ V1 } & V2 & $\mathbf{R}$ \\
\hline 1 & Kualitas Materi Bahan Ajar & 4 & 3,08 & 3,54 \\
\hline 2 & $\begin{array}{l}\text { Kesesuaian Bahan Ajar Berdasarkan Pendekatan } \\
\text { Experiental Learning }\end{array}$ & 3,25 & 3,5 & 3,375 \\
\hline 3 & Kesesuaian Bahan Ajar dengan Syarat Didaktik & 3 & 3,25 & 3,125 \\
\hline 4 & $\begin{array}{l}\text { Kesesuaian Bahan Ajar dengan Ketatabahasaan } \\
\text { Yang Baik Dan Konstruk }\end{array}$ & 3 & 3,27 & 3,135 \\
\hline 5 & Kesesuaian Bahan Ajar dengan Syarat Teknis & 3 & 3,08 & 3,04 \\
\hline & Rata-rata & 3,25 & 3,236 & 3,243 \\
\hline
\end{tabular}

Berdasarkan tabel 2, dapat dikatakan bahwa kualitas materi bahan ajar; dan kesesuaian bahan ajar berdasarkan pendekatan experiental learning adalah sangat valid; kesesuaian bahan ajar dengan syarat didaktik; kesesuaian bahan ajar dengan ketatabahasaan yan baik dan konstruk; kesesuaian 
bahan ajar dengan syarat teknis adalah valid. Selanjutnya disajikan komentar dan saran validator terhadap kevalidan bahan ajar yang telah dikembangkan.

1. Tambahkan penjelasan "experiential learning” dalam kata pengantar dan pendahuluan.

2. Sebaiknya setiap judul sub materi diletakkan di awal halaman.

3. Nama table dan nama gambar agar dilengkapi.

4. Jenis hurup harus konsisten. Misal untuk sub judul sama semua, untuk masalah sama semua.

Tidak terlalu banyak jenisnya.

Kesimpulan: Bahan ajar layak diujicobakan dengan revisi sesuai saran

Selain divalidasi oleh validator, bahan ajar ini juga diedarkan kepada tiga orang guru sebagai praktisi pendidikan di daerah yang berbeda. Berikut disajikan pertanyaan dan tanggapan guru terhadap bahan ajar yang telah dikembangkan.

1. Bagaimana pandangan anda terhadap bahan ajar yang dikembangkan ini dari aspek:

a) Format modul (cover, bentuk tulisan, gambar rajah, dll)

Format modul secara keseluruhan sudah baik, gambar pada modul sudah bervariasi dan warna pada modul juga menarik.

b) Penerapan pendekatan pembelajaran yang digunakan

Penerapan pendekatan pembelajaran yang digunakan yaitu experiential learning. Secara keseluruhan pendekatan pembelajaran yang digunakan sudah baik.

c) Berdasarkan pendekatan pembelajaran yang digunakan dalam bahan ajar, apakah tentang konsep yang dipelajari akan dapat dicapai siswa

Dengan menggunakan pendekatan pembelajaran yang ada pada modul ini, konsep mengenai pelajaran yang dipelajari akan mudah dicapai.

d) Soalan atau latihan yang diberikan

- Secara keseluruhan latihan yang diberikan sudah baik, namun perlu ditambahkan pada modul 1 cara membuat tabel atau diagram, karena pada IPK ada dicantumkan membuat tabel atau diagram, tetapi pada modul 1 belum terlihat kegiatan siswa untuk membuat tabel atau diagram.

- Pada modul 2 di kegiatan siswa ada tabel ukuran sepatu siswa dan ukurannya sudah ditentukan. Sebaiknya ukuran dikosongkan agar siswa yang mengisi sesuai dengan ukuran sepatu siswa.

- Pada kegiatan inquiri di modul dua (mengenai rata-rata) terdapat tabel bahan baku, pada bahan baku tersebut terdapat sayuran, disarankan agar sayuran tersebut diganti dengan bahan baku lainnya seperti garam, mentega, atau bahan baku lainnya yang lebih kontekstual.

e) Aktivitas langsung atau praktik "hands-on" dan eksperimennya

Aktivitas yang ada pada bahan ajar sudah kontektual dan siswa langsung terlibat aktif didalamnya 
2. Bagaimanakah pandangan anda terhadap empat aspek pendekatan experiential learning (yaitu pemberian pengalaman konkrit, pemerhatian/pengamatan/observasi yang bersifat reflektif, konseptualisasi/penyimpulan tentang konsep dan eksperimentasi aktif/penerapan konsep dalam bentuk soalan) yang diaplikasikan dalam bahan ajar ini:

a) Langkah-1; Pemberian pengalaman konkrit bisa berupa permasalahan kontektual ataupun tidak. Permasalahan kontekstual yang diberikan pada bahan ajar ini sudah baik dan up to date dengan permasalahan yang ada sekarang

b) Langkah-2; Pemerhatian reflektif bisa berupa proses pengumpulan data terkait lalu diteliti/observasi sebagai jalan untuk menemukan konsep.

Pada langkah reflektif ini sudah baik.

c) Langkah-3; Konseptualisasi abstrak maksudnya adalah berdasarkan pemerhatian reflektif lalu siswa coba menyimpulkan tentang konsep yang sedang dipelajari.

Pada bahan ajar ini langkah konseptual abstrak ini sudah terlihat dengan jelas pada masingmasing modulnya

d) Langkah-4; Ekperimentasi aktif, kalau dalam matematika maksudnya adalah mencoba menerapkan konsep yang sudah ditemukan tadi dalam menyelesaikan soal, soal-soal latihan.

Pada bahan ajar ini langkah ekperimentasi aktif juga sudah terlihat pada masing-masing modulnya

3. Bagaimanakah pandangan anda terhadap bahan ajar yang peneliti kembangkan ini secara keseluruhan.

Secara keluruhan bahan ajar ini sudah baik, hal ini dapat terlihat pada setiap kegiatan yang ada pada bahan ajar sudah dirinci dengan jelas serta pada masing-masing modul dilengkapi dengan warna dan gambar yang menarik. Namun perlu diperbaiki pada kesalahan pengetikan

Pada aspek kesesuaian materi dengan tujuan pembelajaran bahan ajar yang dikembangkan diperoleh nilai rata-rata validasi sebesar 3,0 yang dapat dikategorikan valid. Maksud dari nilai 3,0 tersebut adalah materi yang disajikan dalam bahan ajar yang dikembangkan lengkap dan sesuai dengan tujuan pembelajaran yang diharapkan. Pada poin keakuratan materi mendapat nilai rata-rata validasi sebesar 3,875 yang dikategorikan sangat valid. Maksud dari nilai tersebut adalah konsep/materi yang disajikan benar dan tepat, dilengkapi dengan ilustrasi materi yang sesuai, istilah, notasi, dan simbol yang sesuai serta contoh soal dan soal latihan yang sesuai dengan materi yang dipelajari. Sedangkan untuk poin penyajian materi memperoleh nilai rata-rata 3,75 yang dikategorikan sangat valid, dengan arti bahwa urutan materi pada bahan ajar terurut secara sistematis sesuai dengan tingkat kemampuan siswa dengan memberikan informasi pendukung yang sesuai dengan materi yang disajikan serta berpotensi melatih berpikir tingkat tinggi siswa. Ketiga poin yang telah dijelaskan merupakan aspek pendukung terhadap kualitas materi bahan ajar yang secara keseluruhan aspek kualitas materi bahan ajar mendapat nilai rata-rata 3,54 yang dikategorikan sangat valid. 
Aspek kedua yang dinilai pada bahan ajar yang dikembangkan adalah aspek kesesuaian bahan ajar dengan pendekatan Experiental Learning. Aspek ini mendapat nilai rata-rata validasi sebesar 3,375 yang dikategorikan sangat valid. Nilai 3,375 berarti bahwa bahan ajar yang dikembangkan berasaskan pendekatan Experiental Learning yang memberikan pengalaman konkrit melalui pemberian masalah kontekstual pada kegiatan siswa, memberi ruang kepada siswa untuk menyelidiki/ mengobservasi yang bersifat reflektif, memberi ruang kepada siswa untuk menyimpulkan konsep, serta memberikan soal latihan sebagai bentuk mengeksperimenkan konsep yang ditemukan. Selanjutnya dilakukan penilaian terhadap aspek kesesuaian bahan ajar dengan syarat didaktik, pada aspek ini diperoleh nilai rata-rata sebesar 3,125 yang dikategorikan valid. Aspek ini meliputi kesesuaian bahan ajar dengan kemampuan siswa yang mendapat nilai 3,25 yang dikategorikan sangat valid. Dikategorikan sangat valid karena bahan ajar dapat digunakan dengan baik oleh siswa yang lamban, sedang, maupun pandai karena bahan ajar menekankan pada proses pemecahan masalah.selain itu juga mencakup aspek kegiatan pada bahan ajar yang dapat merangsang siswa, aspek ini mendapat nilai rata-rata 3,0 yang dikategorikan valid. Nilai 3,0 tersebut memiliki arti bahwa bahan ajar memiliki variasi stimulus melelui berbagai aktifitas siswa yang dapat mengembangkan kemampuan komunikasi, sosial, dan kemahiran berpikir siswa.

Selanjutnya penilaian pada aspek kesesuaian bahan ajar dengan ketatabahasaan yang baik dan konstruk memperoleh nilai rata-rata validasi sebesar 3,135 yang dikategorikan valid. Aspek ini mencakup penilaian terhadap ketepatan penggunaan bahasa dan kalimat dengan nilai 3,15, pemilihan pertanyaan dan sumber belajar dengan nilai 3,25, serta tujuan dan identitas bahan ajar dengan nilai rata-rata 3,0. Ketepatan penggunaan bahasa dan kalimat mendapat nilai 3,15 yang dikategorikan valid dengan maksud bahwa penggunaan bahasa pada bahan ajar sesuai dengan tingkat berpikir siswa dengan menggunakan bahasa yang komunikatif dan tidak menimbulkan makna ganda serta menggunakan struktur kalimat yang jelas. Selanjutnya pemilihan pertanyaan dan sumber belajar dengan nilai 3,25 dikategorikan sangat valid, berarti tingkat kesukaran pertanyaan sesuai dengan tingkat kemampuan siswa dengan memberikan ruang yang cukup untuk jawaban siswa. Sedangkan tujuan dan identitas bahan ajar dengan nilai rata-rata 3,0 dikategorikan valid, yang artinya bahan ajar mencakup tujuan pembelajaran dan terdapat kelengkapan identitas siswa.

Terakhir dilakukan penilaian terhadap aspek kesesuaian bahan ajar dengan syarat teknis yang mendapat nilai rata-rata validasi sebesar 3,04 yang dikategorikan valid. Aspek ini mencakup beberapa poin yaitu tulisan dengan nilai 3,15, gambar dengan nilai 3,125, dan tampilan dengan nilai 3,0 yang setiap poin dikategorikan valid. Tulisan mendapat nilai 3,15 memiliki arti tulisan pada bahan ajar dapat dibaca dengan jelas, gambar dengan nilai 3,125 berarti gambar pada bahan ajar ditampilkan dengan ukuran yang tepat dan gambar yang disajikan sesuai dengan materi pembelajaran, sedangkan tampilan mendapat nilai 3,0 berarti cover bahan ajar, isi, dan petunjuk penggunaan bahan ajar disajikan dengan jelas dan menarik. 
Selanjutnya beberapa pendapat/ tanggapan guru dan siswa terhadap bahan ajar yang dikembangkan dirangkum seperti berikut: terdapat beberapa kesalahan dalam penulisan. Guru menyarankan untuk menyajikan masalah yang paling dekat dengan siswa agar siswa semakin memaknai belajarnya. Selain itu guru juga menyarankan adanya penguatan konsep oleh pendidik terkait konsep rumus yang ditemukan siswa melalui lembar kerja siswa. Beberapa pendapat/ tanggapan guru dan siswa yang diperoleh menjadi dasar untuk melakukan revisi terhadap bahan ajar yang dikembangkan sebelum diimplementasikan.

\section{KESIMPULAN}

Bahan ajar dengan pendekatan Experiental Learning materi statistika dan peluang untuk siswa kelas VIII SMP/MTs terbukti valid dan memiliki efek potensial terhadap kemahiran berpikir tingkat tinggi siswa. Hasil penelitian menunjukkan bahwa bahan ajar telah valid dari kualitas materi bahan ajar, kesesuaian dengan pendekatan Experiental Learning, kesesuaian dengan syarat didaktik, kesesuaian dengan ketatabahasaan yang baik dan konstruk, serta kesesuaian dengan syarat teknis dengan kriteria sangat valid. Berdasarkan pembahasan dan simpulan disarankan agar para pendidik mulai membiasakan para siswa untuk menyelesaikan soal-soal yang berorientasi pada kemampuan berpikir tingkat tinggi.

\section{UCAPAN TERIMAKASIH}

Artikel ini merupakan publikasi hasil penelitian dengan skema Penelitian unggulan universitas Tahun 2020 menggunakan dana yang bersumber dari DIPA UNRI. Oleh karena itu penulis mengucapkan terimakasih kepada Pimpinan LPPM dan DIPA UNRI atas dukungan pendanaannya demi kesuksesan penelitian ini.

\section{DAFTAR PUSTAKA}

Alim, JA, at all. 2020. Development of Learning Flow for KPK Based on Interactive Multimedia Assisted RME Based on Students PGSD UNRI. Journal of Physics: Conference Series, 2020, 1655, 012045, 1742-6596 https://iopscience.i

Abosalem, Y. (2016). Assessment Techniques and Students' Higher-Order Thinking Skills. International Journal of Secondary Education, 4(1), 1. https://doi.org/10.11648/j.ijsedu. 20160401.11.

Branch, R. M. 2009. Instructional Design: The ADDIE Approach.ISBN 978-0-387-09505-9, e-ISBN 978-0-387-09506-6. New York: Springer.

Brouwn A. \& Green T.D (2011) The essential of instructional design connecting fundamental principles with prosess and practice.boston: person

Elfis Suanto, Effandi Zakaria, dan Siti Mistima Maat. 2017. Penerapan Pembelajaran Pengalaman dalam Pendidikan Matematika: Sebuah Kajian Awal. Prosiding Seminar Serantau ke-VII 
bidang Pendidikan, Fakulti Pendidikan, Universiti Kebangsaan Malaysia, Bangi, Selangor Darul Ehsan, Malaysia.

Evans, N. J., Forney, D. S., \& Guido-DiBrito, F. 1998. Student development in college: Theory, research, and practice. New York: Jossey-Bass.

Kartini. 2011. Peningkatan kemampuan berpikir kritis dan kreatif serta belief matematis siswa Sekolah Menengah Atas melalui pembelajaran Inkuiri Alberta. Disertasi Doktor , Universitas Pendidikan Indonesia.

King, F., Goodson, L., \& Rohani, F. (2011). Higher Order Thinking Skills: Definitions, strategies, Assessment. Center for advancement of learning and assessment. Tallahassee: FL : Florida State University. Retrieved from www.cala. fsu.edu

Kolb, D. A. 1984. Experiential Learning as a source of development. New Jersey: Prentice Hall.

Mahdiansyah dan Rahmawati. 2014. Literasi Matematika siswa pendidikan menengah: Analisis menggunakan desain tes Internasional dengan konteks Indonesia. Jurnal Pendidikan dan Kebudayaan. Vol.20 (4) 452-469

Ngah, N., Ismail, Z., Tasir, Z., \& Said, M. N. H. M. (2017). Students' Higher Order Thinking Skills and Their Relationships with Problem Posing Ability. Advanced Science Letters, 23(4), 28762879. https://doi. org/10.1166/asl.2017.7589

Nursalam, Angriani, A. D., Darmawati, Baharuddin, \& Aminuddin. (2018). Developing Test Instruments for Measurement of Students' High-Order Thinking Skill on Mathematics in Junior High School in Makassar. Journal of Physisc, 1020(12169), 1-5. https://doi. org/10.1088/1742-6596/1028/1/01216

Raga, G, dkk. 2014. Model Experiential Learning terhadap Keterampilan Berpikir Kritis IPA Kelas V Kecamatan Sukasada. EJournal Mimbar PGSD Universitas Pendidikan Ganesha Jurusan PGSD. Vol. 2, No. 1 Tahun 2014.

Sa'dun Akbar. 2016. Instrumen Perangkat Pembelajaran. Bandung: Remaja Rosdakarya.

Sari, Y.P. 2013. Penerapan Model Experiential Learning pada Materi Keanekaragaman Biota Laut untuk Meningkatkan Keterampilan Proses dan Kemampuan Berpikir kritis. Tesis tidak diterbitkan. Bandung: Universitas Pendidikan Indonesia.

Silberman, M. 2015. Handbook Experiential Learning Strategi Pembelajaran dari Dunia Nyata. Bandung: Nusa Media.

Phonapichat, P., Wongwanich, S., \& Sujiva, S. (2014). An Analysis of Elementary School Students' Difficulties in Mathematical Problem Solving. Procedia - Social and Behavioral Sciences, 116(2014), 3169-3174. https://doi.org/10.1016/j.sbspro.2014.01.728 